\title{
Research on Community Residents' Perception and Attitude towards Tourism Impacts in Ancient City of Xingcheng
}

\author{
Mei Han ${ }^{\mathrm{a}}$, Weikang Zhang, Huan Meng, Tong Zhang, Zhi Zhang ${ }^{\mathrm{b}^{*}}$ \\ College of Forestry, Shenyang Agricultural University, Shenyang, Liaoning, 110866, China \\ a1362682921@qq.com, ${ }^{\text {bsauzz@163.com }}$ \\ ${ }^{*}$ corresponding author
}

\begin{abstract}
Keywords: Tourism Impacts, Residents Perception and Attitude, Community participation, Ancient City of Xingcheng
\end{abstract}

Abstract. This paper employed the questionnaire method to research the community residents' perceptions and attitudes toward tourism impacts of residents in ancient city of Xingcheng. As indicated, the local residents believed that tourism development had not lead to environmental degradation, but improved community environment. Community residents adopted a neutral attitude on the negative influence of social cultural perception, which indicated that foreign culture had little influence on the local customs. Tourism increased employment and improved income level, which made community residents had a positive perception about the tourism economy. Price increasing had less impact on the community residents' life. Most local residents without highly educated are lack of capital and ability to participate in tourism operations, nevertheless they highly not only support the development of tourism, but also satisfy with the current situation of tourism.

\section{Literature Review}

Murphy proposed community residents to participate in tourism In 1985, since then more and more scholars have paid attention to it[1]. Winston Husbands elucidated it is correlative of the attitude of the residents toward the tourism industry with the development of the local tourism industry [2]. Simmons mentioned that a clean environment, well-educated residents and long-term heritage of virtue could enhance the image of local tourism and attract more tourists[3]. Christina Aas, Adele Ladkin, and John Fletcher concluded that the establishment of effective communication channels could improve the relationship between the stakeholders of the scenic spot and the local tourism industry, which was conducive to community residents to participate in tourism decision-making and management activities [4].

In China, Jie Li, Xiping Zhao indicated that the community residents participating in tourism, may have both positive and negative impacts on local people and environment[5]. Bao Jigang announced that the participation of community residents was great significance to the development of tourism[6]. Liu Jinghui proved that various problems would arise if the loss of community residents involved in the tourism process were ignored, so the advantages of community residents to participate in tourism couldn't be underestimated[7]. Song Peng proposed that community residents were important stakeholders, and tourism development could not be separated from the community[8]. Wang Qiong thought that the community residents' perception of the tourism impact played a vital role in the sustainable development of the scenic spot[9]. Jia Yanju said that encouraging community residents to participate in tourism development was an effective means to improve the positive impact of tourism and reduce the negative impact[10]. 


\section{Research Contents and Methods}

The ancient city of Xingcheng lies in Liaoning province, which was established in Ming Dynasty. On the basis of field investigation, the paper analyzed the residents perception of tourism impact about economy, culture and environment by statistical analysis the indexes such as dispersion degree and approval rate.

The questionnaire consists of three parts. First, employs the questionnaire method to research the community residents' perceptions of tourism impacts. Second, collecting information what about resident participation in tourism planning and benefit from the tourism. Third, understanding the basic situation of respondents.

The investigation was conducted in April 2016 by using Likert scale to score five points. The respondents were local residents of ancient Xingcheng. By random sampling, 200 questionnaires were issued, and the recovery rate was $100 \%$. Among them, 29 were invalid questionnaires, and the effective rate was $86 \%$.

\section{Results and Analysis}

Current Situation of Residents' Participation in Tourism. As we can seen from Table 1, 70.2\% of the local people were willing to work in the tourism sector, $75.4 \%$ of the local people thought that residents can participate in tourism development, planning and construction, $64.9 \%$ of the residents were willing to participate in tourism development, planning and construction. Although only few local residents really participate in tourism development, planning and construction, they highly support the tourism development. There are $35.1 \%$ of the local residents were not willing to participate in tourism development, this part of the respondents are characterized by: far from the ancient city core attractions, work and tourism are not related with tourism and lack of tourism skills. $29.8 \%$ of the local people do not want to work in the tourism sector, the reason is that low wages, job promotion is unlikely and lack of ability. The above data show that community residents have a higher enthusiasm to participate in tourism development, but few have the opportunity to participate in it, let alone express their views and attitudes, which shows that increasing community participation is very significant.

Table 1 Willingness of community residents to participate in tourism development

\begin{tabular}{lccc}
\hline Describes items & Attitudes & Respondents & Percentage(\%) \\
\hline Would you like to work in the tourism sector? & Yes & 120 & 70.2 \\
& No & 51 & 29.8 \\
If residents can be very good to participate in tourism & Yes & 129 & 75.4 \\
development, planning and construction? & No & 42 & 24.6 \\
Are you willing to participate in tourism development, & Yes & 111 & 64.9 \\
planning, construction? & No & 60 & 35.1 \\
\hline
\end{tabular}

Participation of community residents in tourism planning was shown in table $2 ., 89.5 \%$ of the community didn't know the ancient city's tourism planning, construction and protection programs, only $19.9 \%$ of the community residents involved in tourism development, planning and construction, they are mainly scenic employees and village cadres, $84.2 \%$ of community residents referred that the tourism development department did not ask their attitude toward tourism development, planning and construction. $15.8 \%$ of the community residents have commented on tourism planning, most of them are private owners, ordinary villagers know little about the scenic tourism planning, most of them haven't participated in tourism planning, and tourism planning program have not seen at all. Tourism development departments ignore the community residents' 
views of tourism development will inevitably lead to obstacles to the future development of tourism.

Table 2 Actual situation of community residents' participation in tourism planning

\begin{tabular}{lccc}
\hline Describes items & Options & Respondents & Percentage (\%) \\
\hline If tourism development departments consult you about tourism & Yes & 27 & 15.8 \\
development, planning and construction? & No & 144 & 84.2 \\
& Yes & 34 & 19.9 \\
$\begin{array}{l}\text { Do you participate in local tourism development, planning and } \\
\text { construction? }\end{array}$ & No & 137 & 80.1 \\
$\begin{array}{l}\text { Travel planning, construction and protection of the ancient city } \\
\text { program have shown to you? }\end{array}$ & Yes & 18 & 10.5 \\
\hline
\end{tabular}

The income of community residents involved in tourism. By visiting the ancient city of Xingcheng we found that residents participate in tourism lack of characteristics, the sale of tourist souvenirs can be seen everywhere, but most of the same, competition is very fierce, many private owners reflect that business is getting increasingly hard and different to earn money. The ancient city gathered around snacks, along the street to peanut cakes making become a scene, there are mainly small-scale hotels, and there monthly income is around 2501-4000 Yuan. It can be seen from table 3 that the percentage of beneficiaries and non-beneficiaries from tourism is $45 \%$ and $55 \%$, no big difference, which indicates that there are a considerable number of people in the community who are not involved in the development of tourism. And most residents benefit less from tourism. As for tourism business activities, lot of people operate hotels and shops. The survey found that most of those who did not participate in the tourism industry were mainly farmers, $31.5 \%$ of them lack of funds, $17.0 \%$ of them had a poor geographical location, and $10.1 \%$ had no manpower, so capital problem is the main reason for restricting Xingcheng city community residents to participate in tourism.

Table 3 Tourism income analysis of community residents

\begin{tabular}{|c|c|c|c|}
\hline Describes items & Options & Respondents & Percentage $(\%)$ \\
\hline \multirow{2}{*}{$\begin{array}{l}\text { Have you benefited from the development } \\
\text { of the local tourism industry? }\end{array}$} & \multirow{2}{*}{$\begin{array}{l}\text { Yes, I have } \\
\text { No, I haven't }\end{array}$} & 77 & 45.0 \\
\hline & & 94 & 55.0 \\
\hline $\begin{array}{l}\text { What is the proportion of your income } \\
\text { from tourism development to total } \\
\text { household income? }\end{array}$ & $\begin{array}{c}0 \\
1 \%-25 \% \\
26 \%-50 \% \\
51 \%-75 \% \\
76 \%-100 \%\end{array}$ & $\begin{array}{c}48 \\
84 \\
21 \\
6 \\
12\end{array}$ & $\begin{array}{l}28.3 \\
48.9 \\
12.3 \\
3.5 \\
7.0\end{array}$ \\
\hline $\begin{array}{l}\text { At present, in what form you are involved } \\
\text { in tourism business activities? }\end{array}$ & $\begin{array}{c}\text { Hotel } \\
\text { Restaurant } \\
\text { Store } \\
\text { Tourist traffic } \\
\text { Others }\end{array}$ & $\begin{array}{l}12 \\
33 \\
38 \\
18 \\
70\end{array}$ & $\begin{array}{l}7.0 \\
19.3 \\
22.3 \\
10.5 \\
40.9\end{array}$ \\
\hline $\begin{array}{l}\text { What are your reasons for not } \\
\text { participating in the tourism industry? } \\
\text { (If yes, no need to answer) }\end{array}$ & $\begin{array}{c}\text { Lack of funds } \\
\text { Lack of manpower } \\
\text { Can't do business } \\
\text { Poor geographical location } \\
\text { Others } \\
\text { Have }\end{array}$ & $\begin{array}{l}54 \\
17 \\
21 \\
29 \\
19 \\
31\end{array}$ & $\begin{array}{l}31.5 \\
10.1 \\
12.0 \\
17.0 \\
11.3 \\
18.1\end{array}$ \\
\hline
\end{tabular}

Perception and Attitude of Community Residents to Tourism Impact. Community Residents' perceptions on tourism economy impact. A total of 9 items to determine community Residents' perceptions on tourism economy impact, shown as table 4 that local people opposed to the opinion that tourism leads to the gap between rich and poor. Residents do not agree with the attitude that tourism caused the problem. Community residents' perceptions toward "tourism 
increases employment opportunities", "tourism promotes the local economic development", "tourism attracts more investment" are positive, the average are as follows 4.035,4.193,4.228. Standard Deviation are as follows 0.611, 0.684, 0.521, the average is high and the Standard Deviation are small, indicating that the three items get the community residents generally recognized. Approval rates up to $80.7 \%, 84.2 \%, 87.2 \%$. The residents of the community felt strongly about the economy. "Only a small number of local residents benefited from tourism," "tourism industry improved the living standards of community residents," "tourism industry raised the local price" the three items approval rate are not high, respectively $63.2 \%, 61.4 \%$ and $64.9 \%$. More community residents have a neutralizing attitude toward the negative impact of economic. Generally speaking, the community residents have positive perceptions on tourism economy, which shows that the tourism industry has led to the development of the local economy and negative effects are less, it also brings a certain income to the community residents.

Table 4 Community residents perception of the tourism impact on economy

\begin{tabular}{lccc}
\hline Impact Factor & Mean Value & Standard Deviation & Approval rate(\%) \\
\hline $\begin{array}{l}\text { The tourism industry has increased the income } \\
\text { of the local residents }\end{array}$ & 3.842 & 1.170 & 70.2 \\
$\begin{array}{l}\text { Tourism has increased employment } \\
\text { opportunities for community residents }\end{array}$ & 4.035 & 0.611 & 80.7 \\
$\begin{array}{l}\text { Only a few local people benefit from tourism } \\
\text { Tourism improved community living }\end{array}$ & 3.754 & 1.162 & 63.2 \\
$\begin{array}{l}\text { Tourism contributes to community economic } \\
\text { development }\end{array}$ & 3.639 & 1.119 & 61.4 \\
Tourism industry to attract more investments & 4.193 & 0.684 & 84.2 \\
Tourism development has led to rising prices & 3.719 & 0.521 & 87.2 \\
Tourism development has led to rising prices & 2.035 & 0.953 & 64.9 \\
Tourism led community polarization & 3.947 & 0.939 & 29.8 \\
Tourism raised conmunity land prices & & 0.870 & 66.7 \\
\hline
\end{tabular}

Community residents' perceptions toward tourism negative impact on social and cultural (Table 5) include 9 items, 5 items are positive effects of tourism on local culture and 4 items are negative effects. Specifically, community residents highly agree with the item: "tourism industry is conducive to improving community visibility,". Items about negative impacts of tourism on local culture are as following, "tourism on the local folk customs have a great impact," "reduce the trust between residents", "moral standards decline", "the development of tourism has brought a sense of restlessness ", most local people do not think so, and the average items are all below 3.000, the rate of approval less than $40 \%$, " the development of tourism has brought a sense of restlessness", this item's approval rate only $10.5 \%$, indicating that the ancient city of Xingcheng have a long history, local Community residents very pride of the ancient city culture. The mean value, standard deviation and approval rate for the item: "community residents' ideologies are improved", were 3.491,1.048 and 50.9\%, Indicating that residents are indifferent to this.

By visiting many local people we learn that some of them even discriminate against foreign culture, and despise the uncivilized behavior of tourists. Community residents generally have neutral or opposed attitude toward negative impacts of tourism on society and culture. Tourists who come to the ancient city do not stay a long time, most visitors choose one-day tour, so foreign tourists neither affect local culture, nor lead to the increase of in stainable factors. Most of the residents have been living in the ancient city for generations, and they have a deep love of their city, which is also the main reason for the trust between residents. 
Table 5 Community residents perception of the tourism impact on social and cultural

\begin{tabular}{lccc}
\hline Impact Factor & Mean Value & Standard Deviation & Approval rate(\%) \\
\hline $\begin{array}{l}\text { Tourism is beneficial to improve community } \\
\text { awareness }\end{array}$ & 4.070 & 1.026 & 81.9 \\
$\begin{array}{l}\text { Development of tourism conducive to } \\
\text { community learning foreign culture }\end{array}$ & 3.667 & 0.907 & 33.2 \\
$\begin{array}{l}\text { Tourism conducive to discovery and } \\
\text { development of traditional culture }\end{array}$ & 3.825 & 0.903 & 63.2 \\
$\begin{array}{l}\text { Tourism development of folk have a lot of } \\
\text { impact }\end{array}$ & 2.982 & 1.103 & 36.8 \\
$\begin{array}{l}\text { community residents' ideologies are improved } \\
\begin{array}{l}\text { Improve the interpersonal relationship between } \\
\text { the inhabitants of }\end{array}\end{array}$ & 3.491 & 1.048 & 50.9 \\
$\begin{array}{l}\text { Less confidence among the residents of tourism } \\
\text { development }\end{array}$ & 2.737 & 0.949 & 38.6 \\
$\begin{array}{l}\text { Tourism development of the residents of lower } \\
\text { moral standards }\end{array}$ & 2.333 & 0.930 & 21.5 \\
\begin{tabular}{l} 
Tourism has brought a sense of insecurity \\
\hline
\end{tabular} & 2.105 & 0.888 & 14.0 \\
\hline
\end{tabular}

Community residents' perception of tourism environmental impacts(Table 6). Community environment is clean and tidy, In the afternoon, Visitors begin to leave gradually, the ancient city return to calm again. Survey data and the situation are basically the same, The standard deviation about "the development of tourism caused the community environment quality declined" up to 1.170, indicating that the community residents' attitudes are very different. The effective improvement of community traffic get the consent of most residents, the approval rate of $79.7 \%$. Although the influx of tourists will inevitably destroy the quiet environment of the ancient city, also increased the income of residents, so the survey found that community residents do not have too much resentment, far from the scenery spot is also one of the reason. Government protect policy affected the community residents, and to a certain extend, it's raising the community's environmental awareness, and realize the benefits of tourism development.

Table 6 Community residents perception of the tourism impact on environmental

\begin{tabular}{lccc}
\hline Impact factor & Mean Value & Standard Deviation & Approval rate(\%) \\
\hline $\begin{array}{l}\text { Tourism community caused the environmental } \\
\text { quality declined }\end{array}$ & 3.185 & 1.170 & 35.6 \\
$\begin{array}{l}\text { Tourism development and effectively improve } \\
\text { the community transportation }\end{array}$ & 3.386 & 1.075 & 79.7 \\
$\begin{array}{l}\text { Tourism development undermine community } \\
\text { peace of life }\end{array}$ & 3.912 & 0.981 & 75.4 \\
$\begin{array}{l}\text { Tourism development contributes to improve } \\
\text { the people's awareness of environmental } \\
\text { protection }\end{array}$ & 3.895 & 0.970 & 66.6 \\
\hline
\end{tabular}

Table 7 Community residents' attitudes toward the development of tourism

\begin{tabular}{lccc}
\hline Attitudes & Mean Value & Standard Deviation & Proportion(\%) \\
\hline Development of tourism is good to local people & 3.561 & 0.977 & 54.4 \\
You support the development of local tourism & 4.035 & 0.702 & 87.2 \\
$\begin{array}{l}\text { You are satisfied with the current situation of } \\
\text { tourism }\end{array}$ & 3.579 & 1.162 & 65.2 \\
\hline
\end{tabular}

Attitude of community residents towards the tourism development(Table 7). Although the approval rate of "developing tourism is more good than harm" was only $54.4 \%$, however, $87.2 \%$ of 
the local residents supported the development of the tourism. What the local government should realize is that the satisfaction of residents about the current situation of tourism still has a greater space to improve.

\section{Conclusions}

Local residents highly supported the development of tourism. Their perception of environmental positive impact was strong. They thought that tourism does not cause environment degradation, on the contrary, it improves local circumstance . Community residents had neutral or opposed attitude toward negative impact of tourism on society and culture. Foreign culture did not have significant impact on local customs, and the development of tourism had increased the visibility of the community and the residents' cultural self-confidence. Community residents had positive perception toward the impact of tourism on the economy. The development of the tourism industry has provided more job opportunities and increased family income.

\section{Acknowledgments}

Thanks to the vice professor Zhi Zhang whom be my tutor and the corresponding author of this paper. I enjoyed the great benefit of his instructions concerning the matters which from the graduation project topic selection, formulation and implementation of research plan, to writing and revision of graduation thesis. Without his constant encouragement and patient instruction, this thesis could not be completed. Also, I would like to thank all the teachers who had taught me a lot during the college, and thank Huan Meng, Kang Wei and Tong Zhang for revising the thesis.

\section{Reference}

[1]Murply. PE. Tourism: a community approach[M].Methuen. New York and London, 1985:155 -176.

[2]Winston Husbands. Social Status and Perception of Tourism in Zambia[J]. Annals of Touristm Research, 1989,(2):237-253.

[3]David G Simmons. Community participation in tourism planning [J].Tourism Management, 1994,15(2):98-108.

[4]Christina Aas, Adele Ladkin, John Fleteher. Stakeholder Collaboration and heritage management [J].Annals of Tourism Research.,2005,32(1):28-48.

[5]Li Jie, Zhao Xiping. Community participation in tourism development theory of some economic question [J]. Journal of Tourism, 2001,04:44-47.

[6]Bao Jigang, Sun Jiuxia.Characteristics of Community Participation in Tourism Development [J]. Acta Geographica Sinica, 2006,04:401-413.

[7]Liu Jinghui. Jiangnan town community to participate in tourism development research [D]. Shanghai Normal University, 2007.

[8]Song Peng. Qiang cultural tourism sustainable development of community participation in the study [D]. Chengdu University of Technology, 2012.

[9]Wang Qiong. Kanas scenic community residents tourism impact perception empirical study [D]. Shihezi University, 2015.

[10]Jia Yanju de-gang wang. The dynamic changes of the community residents tourism influence perception and our attitude [J]. Journal of travel, 2015,12:65-73. 